\title{
Determination of Optimal Level of Foreign Reserves in Nigeria
}

\author{
Ishola W. Oyeniran ${ }^{1}$ and Solomon A. Alamu ${ }^{2}$
}

This study adopts the 'buffer stock model' advanced by Frenkel and Jovanovic (1981) to estimate the optimal level of foreign reserves for Nigeria. The Autoregressive Distributed Lag Approach (ARDL) was used to estimate the optimal foreign reserves function. The results show that the Nigeria's optimal reserves level responses to adjustment cost of holding reserves and exchange rate volatility and that import and opportunity cost of reserves holding have insignificant impact on Nigeria's optimal foreign reserves. The short run and long run estimates of the buffer stock model support the theory that foreign reserves holding in Nigeria is more sensitive to the precautionary than mercantilist motives of holding reserves. Thus, it is recommended that the Central Bank of Nigeria $(C B N)$ should implement effective foreign reserves policies that consider exchange rate volatility, oil price volatility and global macroeconomic imbalances.

Keywords: ARDL, exchange rate volatility, import, Nigeria, Optimal, Reserve

JEL Classification: F30, F32, F36

DOI: $10.33429 /$ Cjas.11120.3/5

\section{Introduction}

Foreign reserves represent the amount of external assets held by a nation. These assets include currency, securities, deposit, special drawing rights, monetary gold, etc. (Molapo, 2014). The development of the concept of foreign reserve accumulation originated due to the introduction of central banks and the need to trade in the integrated global economy (Dhar, 2013).

Foreign reserve, like money, is demanded for several reasons. From the literature, two main motives for holding foreign reserves are identified: precautionary and mercantile motives. The precautionary motive involves holding foreign reserves to forestall shortage of funds that normally occur during financial crises to serve as collateral for external debt, thereby improving a country's credit worthiness. It is also used to stabilize currency volatility during

\footnotetext{
${ }^{1}$ Department of Economics, University of Lagos, Nigeria. Tel. +2438068388418, E-mail: wasiuishola35@gmail.com

2 Department of Economics, University of Lagos, Nigeria. Tel. +2438085574448, E-mail: alamuabidemi@yahoo.ca

The views expressed in this paper are solely those of the authors and do not necessarily represent those of the Central Bank of Nigeria.
} 
the occurrence of external shocks (Aizeiuman and Lee, 2005; Kim et al., 2005; Rodriguez and Funk, 2012; Tule et al., 2015). On the other hand, the mercantile view argues that reserve accumulation is used to facilitate exports and direct investment to the export industries (Aizenman and Lee, 2005). It is also of the mercantilist's view that foreign reserves serve to keep real exchange rate devalued against the foreign currencies, especially the US dollar, in order to strengthen the domestic economy (Calvo, Alejandro, and Rudy, 2012; Shijaku, 2012).

Despite its huge benefits, maintaining high level of foreign reserves comes with a lot of risks. First, the value of foreign reserves might decline if there is currency appreciation which could also lead to loss of a country's wealth (Molapo, 2014). Second, continuous reserves accumulation, as noted by Mohanty and Turner (2006), could lead to inflationary risk, monetary imbalances, overheated credit and asset markets and distorted financial system. The third risk that could result from maintaining high level of foreign reserves is the loss of resources that could have been earned if the reserves have been utilised in alternative ways such as investment in the infrastructural facilities (Green and Torgeson, 2007).

Theoretical approaches used in determining what constitute optimal foreign reserves holding can be divided into two: the traditional metric approach and optimization approach. The traditional approach puts forward some indicators that could be used in adjudging reserves adequacy. These indicators include ratio of foreign reserves to imports (import cover), ratio of foreign reserves to short-term debt, ratio of foreign reserves to broad money (M2) and combination metrics (Heller, 1966; IMF, 2003). This approach has been criticized for assuming linearity and lacking micro-founded optimization (Rodriguez and Funk, 2012; Molapo, 2014). The optimization method, on the other hand, postulates that monetary authority will hold certain level of foreign reserves which minimizes expected total costs- consisting of opportunity costs and adjustment costs- of holding reserves. The opportunity cost is defined as the difference between return on capital and reserve, while the adjustment cost is seen as the output loss that could arise when reserve is too low or reach undesirable lower bound (Ben-Bassat and Gottlieb, 1992; Afrin, Sarder and Nabi., 2014; Tule et al., 2015).

Most developing countries accumulate excess foreign reserves without investing them in social overhead capital that may boost the development efforts of their economies (Mohanty and Turner, 2006; Mbeng-Mezui and Duru, 2013; Prabheesh, 2014; Molapo, 2014; Tule et 
al., 2015). Besides discovering that developed countries keep low foreign reserves, MbengMezui and Duru (2013) point out that the average annual excess foreign reserves in African countries in the range of $\$ 165.5$ and $\$ 193.6$ billion is more than the infrastructure financing gap valued at about $\$ 93$ billion per year in these countries. The large build-up of excess foreign reserves in these countries has attracted the attention of scholars toward the exploration of optimal foreign reserves holdings in these economies.

The Nigeria's foreign reserves holding has been unpredictable due to its over reliance on crude oil price. According to CBN (2015) Nigeria's external reserve derives largely from the earnings of crude oil production and sales, and her reserve is highly vulnerable to volatilities that characterize crude oil price in international market. The magnitude of this reserve is intricately linked with crude oil price level that, over the years, defies proper management and prediction. This has constituted a strong impediment to proper and adequate planning and investment of excess reserves in the country's infrastructure and has also affected the stability of exchange rate in the country. Figure 1 shows the percentage changes in Nigeria's foreign reserves and international oil price between 2005 and 2015. From this Figure, it could be deduced that changes in Nigeria's foreign reserves move in the direction of changes in oil price by one year period lag. For instance, the price of crude oil, after a sharp decline in 2009, rose to $\$ 71.21$ in 2010 and $\$ 87.04$ in 2011 representing a percentage change of 22.2 between the two years. The oil price surge resulted into an unprecedented accumulation of Nigeria's foreign reserves, after its decline in 2010, from \$32.64billion in 2011 to \$43.83billionin 2012 (amounting to $34.28 \%$ change). In 2014, crude oil prices began to fall again resulting in another decline in the level of Nigeria's foreign reserves from \$34.24billion in 2014 to \$28.28billion in 2015 .

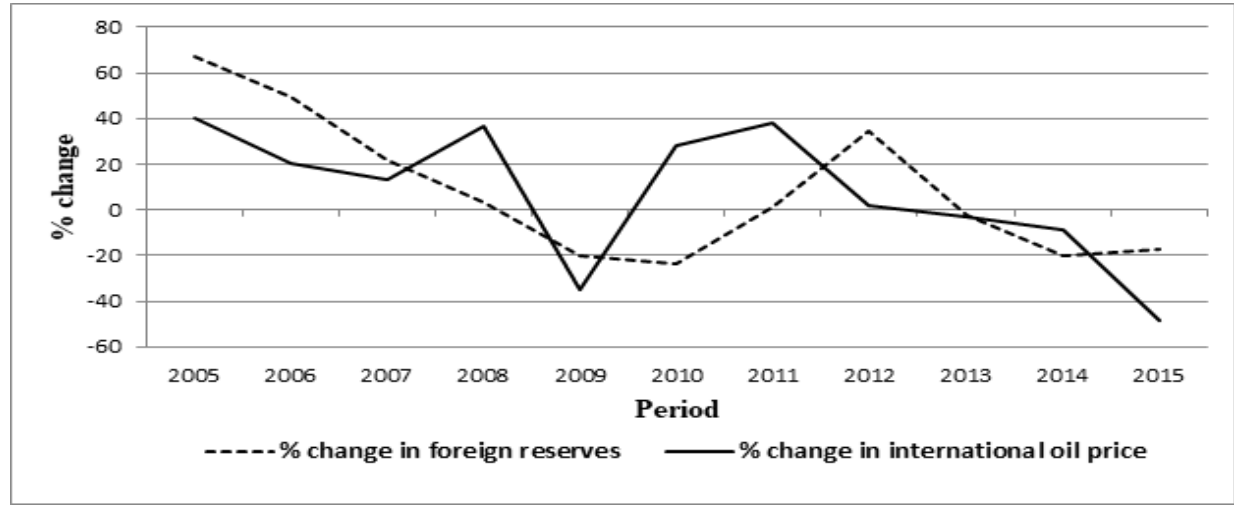


Figure 1: Percentage change in Nigeria's foreign reserve

Also, the IMF article IV consultation report 2017 has complained about the falling of Nigeria's foreign reserves below the recommended adequacy level of 125 percent of the metric. The report claims that, although, the Nigeria's gross foreign reserves increased to $\$ 28.6$ billion in January 2017 from less than \$24 billion in September 2016, it is amounted to 120 percent of the IMF's reserve adequacy metric and was below the recommended floor of the adequacy range of 125 percent of the metric. The fear is that Nigeria may not be able to mitigate external risk and exposures. It is, thus, desirable to know whether the level of foreign reserves maintained by the $\mathrm{CBN}$ is optimal.

More so, most studies on optimal foreign reserves holding focused on the precautionary motive of reserve holdings and are mostly panel studies (see Calvo et al., 2012; Prabheesh (2013); Mbeng-Mezui and Duru, 2013; Daud and Ahmad, 2013). Little efforts have been made to examine both precautionary and mercantile motives of reserve holding in emerging and developing countries, especially in Nigeria. Thus, this paper aims at estimating the optimal foreign reserve holdings for Nigeria with focus on both the precautionary and mercantilist approaches. The study adopts the stock buffer approach developed by Frenkel and Jovanovic (1981) since this approach can be easily modified to suit various motives of reserve accumulation. Estimation of optimal foreign reserves holdings is important since volatile foreign reserves could make a country vulnerable to global financial crisis.

Following this introduction, section 2 focuses on review of related literature. In section three theoretical model and methodology are discussed. The fourth section deals with presentation of results, while the last section concludes the paper.

\section{Literature review}

\subsection{Theoretical Review}

Theoretical literatures on foreign reserves holdings can be broadly grouped into three. The first set of studies in this area examines the adequacy of foreign reserves. This approach sees reserves accumulation as a catalyst for meeting external payments commitment, stabilizing currency volatility during the occurrence of external shocks and avoiding meeting payment of import- sudden-stop (Alfaro and Kanczuk, 2007). This group of studies outlines some indicators that could be used in measuring and evaluating foreign reserves adequacy. For 
instance, Triffin (1960) and IMF (2000) propose import cover reserve adequacy which could be the ratio of reserve to import or 4 months of import covering reserves. Heller (1966) and IMF (2003) recommend foreign reserves that could meet up short-term debt obligation. Similarly, Greenspan (1999) suggests that emerging countries should maintain foreign reserve that is related to their short-term external debt obligation. Kaminsky and Reinhart (1999) and Wijnholds and Kapteyn (2001), on the other hand, consider ratio of foreign reserve to broad money supply as a measure of reserve adequacy. They argue that reserve to broad money ratio can reveal potential risk of capital flight associated with financial crisis.

The second strand of studies in this area, which is the focus of this paper, centers on modeling the optimal foreign reserves holdings. In these studies, optimal level of foreign reserves is defined as that which optimizes the gap between cost and benefit derived from holding reserve. Majority of the studies in this area is based on cost-benefit analysis of reserves preference with the primary assumption of the role of reserves as a self-insurance mechanism against external risks (IMF, 2003; Shikaju, 2012). Only few studies incorporate the mercantile view into their modeling of optimal foreign reserves. The work of Heller (1966) which forms the seminal work in this area states that optimal reserve is attained when marginal cost is equated with marginal benefit from holding reserve. He perceives optimal reserves as a function of variables such as the external debt, level of imports, the opportunity cost of holding reserves, the probability of default and the output cost of default.

On the other hand, a Buffer Stock model of the demand for foreign reserves developed by Frenkel and Jovanovic (1981) sees optimal level of reserve holdings as that which minimizes two costs: the opportunity cost of holding high level of reserve and adjustment cost which emanates from cost of adjusting the current level of reserves to the optimal level when keeping too low foreign reserves.

Ben-Bassat and Gottlieb (1992) argue that Frenkel and Jovanovic's model may not be suitable for most developing economies facing persistent current account deficit. They argued that 'sovereign risk' should be considered when estimating optimum reserves for these countries since they faced balance of payment deficit. Consequently, they focus on precautionary reserve demand and built a model in which optimum reserve is derived by minimizing total cost of holding reserve, comprising sovereign risk and cost of default. However, their model's assumption of perfect capital market on the basis of which sovereign risk is captured is un- 
tenable in most developing countries. Besides, their model is not flexible enough to allow for the mercantile motive of reserves holding as it is the case with the Frenkel and Jovanovic's model (Batten, 1982; Shijaku, 2012).

The third group of studies in this area examines the determinants of foreign reserves. This literature consists of contributions from authors like Batten (1982), Aizenman and Marion (2002), Romero (2005), Irefin and Yaaba (2012), etc. Several factors such as exchange rate volatility, imports, capital account vulnerability, current account vulnerability, volatility of reserves, opportunity cost, etc. have been identified as the drivers of foreign reserves holdings. These factors are not similar for emerging and developed countries. Studies by Romero (2005) and Aizenman and Marion (2002) even identified different factors driving foreign reserves accumulation among emerging countries. While, Romero (2005) identified drivers such as exchange rate volatility and economic openness, Aizenman and Marion (2002) identified trade volatility, exchange rate regime, economic openness, and political considerations as determinants of foreign reserves holdings.

According to Calvo and Reinhart (2002), factors affecting foreign reserves include fluctuations in the valuation of reserves (such as Treasury management of oversea currency debt as in the case of New Zealand), hidden foreign reserves transactions (such as engaging in derivative transactions), accrual of interest rate earnings and deliberate act by monetary authorities to stabilize exchange rate during currency crisis or speculative pressure. Calvo and Reinhart (2002) discover that foreign reserves change frequently in economies with stable exchange rate because these economies intervene in the foreign exchange market by varying their reserve level even when these countries claim they are practicing floating exchange rate regime.

\subsection{Empirical Review}

Most empirical studies such as Prabheesh (2013), Mbeng-Mezui and Duru (2013), Daud and Ahmad (2013), etc. claim that actual foreign reserves holdings in many emerging and developing countries are in excess of optimal foreign reserves. Prabheesh (2013), using the Ben-Bassat and Gottlieb's model, examines the optimal level of foreign reserves for India and found that actual foreign reserves in the country are higher than the estimated optimum level of reserves. Similar result was also found by Daud and Ahmad (2013). In their study of cost of holding foreign reserves in Malaysia, they discover that Malaysia derived benefits 
from holding foreign reserves after the 1997 Asian financial crisis. These benefits are in terms of lower cost and less vulnerability to sudden shocks. They, nevertheless, suggest that reserves holdings in Malaysia are far beyond the traditional benchmark as the reserve could finance 9.3 months of imports. Other studies with similar result include Mbeng-Mezui and Duru (2013); Calvo et al., (2012); Tule et al., (2015) among others. However, in contrast to the studies above, Suheyla and Yaman (2005)'s empirical study on the determination of adequate and optimal reserves in Turkey between 1998 and 2002 shows that actual foreign reserves in Turkey were below the optimal and adequate levels "when a cumulative GDP loss in excess of 5.0 per cent during a financial crisis is imposed on the entire sample period".

Few studies that have modeled the mercantilist view of holding foreign reserves include Batten (1982), Calvo et al., (2012) and Shijaku (2012). To examine the demand for foreign reserve under floating and fixed exchange rate, Batten (1982) modify the Frenkel and Jovanovic's model to accommodate the assumption that external reserves were held to allow for foreign exchange intervention. His empirical result shows that major determinants of foreign reserves are propensity to import, opportunity cost of holding reserves, variability of international payments and receipts, and the size of international transactions. Calvo et al., (2012) discover that, unlike countries in Europe, most East Asian and Latin American countries keep reserves above the optimal reserves level and that gaps between observed reserves and precautionary-motive optimal reserves are moderately induced by the "perceived presence of a lender of last resort, or characteristics such as being a large oil producer". The study, however, fails to recognize the basis for mercantilist motive for reserve accumulation. Similar result was also found by Shijaku (2012). Using a modified Frenkel and Jovanovic's model with aid of ARDL approach, the study suggests that optimum reserves holding in Albania is more sensitive to precautionary than mercantilist motives.

Most studies on optimum reserves are panel or cross-sectional studies (Aizenman \& Marion, 2002; Cheung and Ito, 2007; Park and Estrada, 2009; Calvo et al., 2012; Daud \& Ahmad, 2013 etc). These studies do not capture the individual characteristics of the sampled countries. For instance, Alfaro and Kanczuk (2007) examine the motive of holding both sovereign debt and reserves in emerging economies and discover that the optimal policy for these economies is not to accumulate any reserves. Spurred by the idea of how reliable the traditional method of measuring optimal reserves is Dabla-Norris, Kim and Kazuko 
(2011) develop a cost-benefit approach that captured the precautionary roles of foreign reserves. They compute the optimal level of foreign reserves in selected sample of 49 low income developing countries over the periods 1980-2008. With calibration technique, they establish that the traditional method of ratio of reserve to three months of imports yield an imprecise benchmark of optimal foreign reserves. Mbeng-Mezui and Duru (2013) using the import cover and Wijnholds and Kapteyn method of measuring reserves adequacy discover that African countries' reserves holding surpass their adequate foreign reserves. The study also confirm that the excess reserves in Africa is more than their infrastructure financing gap, and therefore recommends policy makers in Africa to utilise their excess reserves to bridge infrastructural gap necessary for economic development.

Time series studies on optimum foreign reserves holding have been less extensive. Time series studies on optimum reserves holding in Nigeria include; Oputa and Ogunleye (2010), Irefin and Yaaba (2012), Abiola and Adebayo (2013), Tule et al., (2015) etc. Oputa and Ogunleye (2010) and Abiola et al., (2013) in their separate studies of reserves holdings in Nigeria conclude that Nigeria's foreign reserves were adequate based on international benchmarks. Oputa and Ogunleye (2010), however, state that actual reserves, on the average, fall below optimum foreign reserves. Irefin and Yaaba (2012) used ARDL approach to estimate modified buffer stock model of optimum reserve developed by Frankel and Jovanovic (1981) and found that income remains a major determinant of optimum foreign reserves in Nigeria. Spurred by the rising debt burden and declining foreign reserves, Senibi et al., (2016) apply Johansen cointegration and fully modified ordinary least square (FMOLS) technique to investigate the effects of public debt on Nigeria's foreign reserves between 1981and 2013. Their results show that public debt has a positive and significant effect on Nigeria's foreign reserves in the long run. Tule et al., (2015) adopted the Ben-Bassat and Gottlieb (1992) model to examine the optimal level of foreign reserves for Nigeria with quarterly data between 2000 and 2014. The study found that actual reserves were above the optimal reserves for the period. However, it was discovered that the average core reserves in the country was insufficient to make her unsusceptible to possible future occurrence of financial crises.

In a panel study of West African countries, Olomola and Ajayi (2018) investigate the drivers of international reserve for the period of 2005 to 2014. With the aid of a buffer stock estimated through Panel auto-regressive distributed lag (ARDL) approach, it was found that real 
income per capita, import, population, volatilities in proceeds from export and nominal exchange rate have significant effect on international reserve in these countries. However, these authors exclude opportunity cost and foreign reserves adjustment from their model specification. These variables, as indicated by the buffer stock model, are significant drivers of optimum foreign reserves holdings. In another panel study, Sanusi, Meyer and Hassan (2019) use ARDL approach to examine the determinants of foreign reserves in Southern African countries between the periods of 1990 and 2015. They conclude that exchange rate, inflation rate, exports and imports are significant determinants of foreign reserve holdings in the long run. However, in the short run, capital inflows, inflation rate, exports and imports are significant determinants of foreign reserve holdings. The authors conclude that foreign reserves in Southern African countries are significantly driven by the fear of floating" rather than by the "fear of capital". This study also did not capture opportunity and reserves adjustment costs in its model specification. This submission is in line with the findings of Calvo and Reinhart (2002) that most economies do not float their exchange rate as claimed but rather vary their foreign exchange reserves to stabilize their domestic currencies during economic and financial crisis.

From the foregoing, it is noticed that studies examining both the precautionary and mercantile motives of optimal reserve holdings in emerging and developing countries, especially in Nigeria, are scanty. Thus, this study fills this gap. It adopts modified buffer stock model of Frenkel and Jovanovic (1981).

\section{Data and Methodology}

\subsection{Model Specification}

This study adopted a modified buffer stock model of demand for foreign reserve developed by Frenkel and Jovanovic (1981). The model is based on the idea of holding of an optimum level of foreign reserves by central banks. The model sees foreign reserves as inventory of money, which could be used to stabilize the economy during the period of macroeconomic shocks. This model posits that monetary authorities, in maintaining stock of foreign reserves, take note of macroeconomic costs of adjusting international reserves and opportunity cost of holding it. The buffer stock model states that the monetary authorities usually select reserves level that minimizes these two expected costs (Dabla-Norris et al., 2011). This model is adjudged to be flexible and suitable for modifications that allows for estimation of optimum 
reserves holdings based on precautionary and mercantilist approaches (Batten, 1982; Shijaku, 2012).

The theoretical basis for this study is the buffer stock model. The Buffer Stock model formulates reserves function "as a continuous exogenous Wiener process of the form":

$$
\begin{aligned}
& d R(t)=-\mu d t+\sigma d W(t) \\
& R(0)=R_{0}, \quad \mu \geq 0
\end{aligned}
$$

Where, $\mathrm{R}(\mathrm{t})$ represents reserves level at time $\mathrm{t}$ "and $\mathrm{W}(\mathrm{t})$ is a standard Wiener process possessing the properties of simple random walk, with mean $\mu$ and with standard deviation $\sigma$ " (Frenkel and Jovanovic, 1981). According to equation 1, dR(t) is normally distributed with mean $-\mu \mathrm{dt}$ and variance given as $\sigma^{2} \mathrm{dt}$. Thus, the distribution of reserve holdings $\mathrm{R}(\mathrm{t})$ is given by:

$$
R(t)=R_{0}-\mu t+\sigma W(t)
$$

$\mathrm{R}_{0,} \mu$ and $\sigma$ are the optimal or initial reserves holdings, the "deterministic part of the instantaneous change in reserves, and the standard deviation of the change in reserves that comes from Wiener process" respectively. In equation 2, reserve at time t equals initial reserves (assumed to be optimum reserves) minus the displacement constant $\mu$ at time t plus any adjustment cost due to variations in reserves $\sigma$.

From equation 2 , if the reserves are at their optimum level at each period, we expect the displacement constant $\mu$ to be "zero, so the stochastic process that governs changes in reserves is without a drift" (Frenkel and Jovanovic, 1981).

Frenkel and Jovanovic (1981), postulates that monetary authority will hold certain level of foreign reserves which minimizes expected total costs- consisting of opportunity costs of holding reserves (r) and adjustment costs $(\sigma)$ of altering the current level of reserves to the optimal level. That is reserves holding depends on adjustment and opportunity costs.

Following Shijaku (2012), the Taylor (2002)'s second order approximation of the optimum reserves demand can be formulated as follows;

$$
\ln R_{o}=\beta_{0}+\beta_{1} \ln \sigma_{t}+\beta_{2} \ln r_{t}
$$

where $\mathrm{R}_{0}$ represents the optimal reserves holding, $\beta_{0}, \sigma$ and $\mathrm{r}$ are constant term, adjustment and opportunity costs, respectively. Based on equation 3 , the optimal foreign reserve holding 
depends on adjustment and opportunity costs. So that optimum reserve level is that which minimizes the adjustment and opportunity cost.

Also, based on the assumption by Jalil and Bokhari (2008), "that the observed reserves $\mathrm{R}_{t}$ are proportional to optimal reserves up to an error term $\xi_{t}$ ", the following estimable equation is derived,

$$
\ln R_{t}=\beta_{0}+\beta_{1} \ln \sigma_{t}+\beta_{2} \ln r_{t}+\xi_{t}
$$

Since Nigeria reserves are held in terms of months of imports cover, import was included in the model to estimate reserve holdings. Thus equation 4 is modified as given below;

$$
\ln R_{t}=\beta_{0}+\beta_{1} \ln \sigma_{t}+\beta_{2} \ln r_{t}+\beta_{3} \ln I M_{t}+\xi_{t}
$$

where IM is import and its coefficient $\left(\beta_{3}\right)$ is expected to carry a positive sign.

Finally, given that central banks normally use foreign exchange to intervene in market to stabilise the value of the domestic currency (Afrin et al., 2014), and the fear that volatile exchange rate may keep central bankers accumulating reserves of foreign currencies (Calvo and Reinhart, 2002), exchange volatility was added to equation 5. Inclusion of exchange rate also serves the mercantile motive of reserves holdings.

Thus, equation 5 becomes,

$$
\ln R_{t}=\beta_{0}+\beta_{1} \ln \sigma_{t}+\beta_{2} \ln r_{t}+\beta_{3} \ln I M_{t}+\beta_{4} \ln V O L+\xi_{t}
$$

where VOL represents real exchange rate volatility and $\beta_{4}$ is expected to be positive. Parameters in equation 6 will be estimated through the Autoregressive Distributed Lag approach (ARDL).

Measuring opportunity cost of holding reserves is debatable. Edwards (1985) suggests that opportunity cost, termed as penalty rate by Frenkel and Jovanovic (1982), corresponds to the difference between a country's marginal product of capital and interest rate on reserve. However, noting that marginal productivity of capital is difficult to measure due to data unavailability, Edwards (1985) proposes measuring opportunity cost of holding reserves by the spread between interest rate on external debt and return on reserves (LIBOR rate). This approach was also adopted by authors such as Ben-Bassat and Gottlieb (1992), Rodriguez and 
Funk (2012), Prabheesh (2013) and Tule et al., (2015) etc. However, some studies have used single rate to capture opportunity cost of holding reserves on the premise that data on reserves investment are unavailable. These variables include call money rate (Jalil and Bokhari, 2008), sovereign spread (Daud and Ahmad, 2013). For this study, as in Jalil and Bokhari (2008), the opportunity cost of holding reserve was proxied with call money rate.

Foreign reserve was measured as total reserve including gold in US dollar. Adjustment Cost is the output loss that could arise when reserve is too low or reach undesirable lower bound. That is, the cost of adjustment necessary that will facilitate a positive balance of payment when reserves are very low. Following Jalil and Bokhari (2008) and Shijaku (2012), this study measured adjustment cost as volatility of reserve. Import was proxied by total nominal import in US dollar. Official local currency to US dollar was used to proxy exchange rate. Following Tule et al., (2015), reserves volatility and exchange rate volatility were measured using the Generalised Autoregressive Conditional heteroscedaticity (GARCH) approach.

\subsection{Method of Analysis}

Parameters from equation 6 were estimated through the bounds testing (or Autoregressive Distributed Lag (ARDL)) cointegration procedure, developed by Pesaran, Shin and Smith (2001). The ARDL procedure is relatively more efficient in small or finite sample data sizes as is the case in this study (Kakar, Kakar and Waliullah, 2010). The main requirement of the approach is for variables to be stationary at level and/or at first difference (Fosu and Magnus, 2006).

The ARDL cointegration approach involves test of unit root properties of time series, confirmation of existence of a long-run relationship between observed foreign reserves and all other regressors stated in equation 6 through bound cointegration test, and obtaining the estimates of long run and short run parameters of equation 6 through dynamic error correction method (Fosu and Magnus, 2006, Oyeniran and Maryam, 2015).

In addition to confirming the unit root properties of variables used in this study and verifying the existence of long run relationship among these variables, various diagnostic tests will be conducted. These include serial correlation test, heteroscedasticity test and functional model test. 


\subsection{Sources of Data}

Data used in this study are monthly time series spanning 2002:1 to 2016:12. The variables of interest are foreign reserve, call rate, import and exchange rate. All Data were sourced from the Central Bank of Nigeria's statistical bulletin, 2018.

\section{Results and Interpretation}

\subsection{Unit Root Test}

The unit root property of each variable was tested with Augmented Dickey-Fuller (ADF) and Phillip Perron tests. The test statistics and critical values of ADF and PP were presented in Table 1. The test statistics indicate that adjustment cost and exchange rate volatility and opportunity cost are stationary at level since the calculated t-ratio of ADF and PP of each variable is greater than its respective 5\% critical value. Foreign reserve and import become stationary at first difference. Since, none of these variables is stationary at second difference; the use of ARDL method is justified.

Table 1: Results of Unit root tests

\begin{tabular}{llllllll} 
Variable & Level & $\begin{array}{l}\text { ADF } \\
1^{s t} \text { Differ- } \\
\text { ence }\end{array}$ & $\begin{array}{l}5 \% \\
\text { Critical } \\
\text { value }\end{array}$ & Level & $\begin{array}{l}\text { PP } \\
1^{\text {st }} \text { Dif- } \\
\text { ference }\end{array}$ & $\begin{array}{l}5 \% \\
\text { Critical } \\
\text { value }\end{array}$ & $\begin{array}{l}\text { Order of } \\
\text { Integra- } \\
\text { tion }\end{array}$ \\
\hline $\ln \mathrm{R}$ & -1.217 & -6.851 & -3.432 & -1.394 & -11.202 & -3.432 & $\mathrm{I}(1)$ \\
$\ln \sigma$ & -12.251 & -18.508 & -2.876 & -12.347 & -32.018 & -2.876 & $\mathrm{I}(0)$ \\
$\ln \mathrm{n}$ & -4.454 & -7.539 & -2.876 & -6.781 & -21.809 & -2.876 & $\mathrm{I}(0)$ \\
$\ln \mathrm{IM}$ & -3.575 & -14.193 & -3.432 & -5.073 & -33.402 & -3.432 & $\mathrm{I}(1)$ \\
$\ln \mathrm{VOL}$ & -6.287 & -23.013 & -2.876 & -9.696 & -25.708 & -2.876 & $\mathrm{I}(0)$ \\
\hline
\end{tabular}

Source: computed by Authors

\subsection{Bounds tests for Cointegration}

Table 2 presents the result of bounds testing approach to co-integration. From the result, it could be concluded that a long run relationship exists between the foreign reserves and all the independent variables used in this study. This arises from the fact that the calculated Fstatistic is significant at 5 percent critical level and is greater than the Pesaran's critical lower bound value of 2.06 and upper bound values of 3.24. 
Table 2: Results from Co-integration test

\begin{tabular}{lllll}
\hline Variable & lag & F-stat. & P-value & Conclusion \\
\hline $\ln \mathrm{R}$ & 1 & 5.3240 & 0.0000 & No co-integration \\
\hline Computed by Authors. & & & \\
Pesaran 5\% critical value & - lower bound: & 2.86; upper bound: 4.01
\end{tabular}

\subsection{Long run estimates}

The long run estimates of the optimal foreign reserves function derived from the ARDL method are presented in Table 4. The measure of goodness of fit (R-squared) of the model is very high (0.99) and statistically significant (P-value of F-statistic is less than 0.05). This shows that the model is adequate in explaining the behaviour on foreign reserves in Nigeria.

The long-run estimates of foreign reserves function show that a positive significant relationship exists between foreign reserves and adjustment cost. In other words, one-month lag of adjustment cost of declining foreign reserves have a significant positive impact on current foreign reserves. This implies that the $\mathrm{CBN}$ consciously strives to accumulate foreign reserves in the face of uncertainty and takes cognizance of vulnerabilities that come with low foreign reserves.

While, lag of call money rate, import and exchange rate volatility (EXR) are inversely related to foreign reserves, only exchange rate volatility has a significant negative impact on foreign reserves in Nigeria. This corroborates the belief that the CBN uses foreign reserves as a tool for cushioning the effect of fluctuating exchange rate. The CBN draws down the country's reserves to stabilize the country's currency.

From the long run estimates (presented in Table 3), the coefficient of import has a negative sign and it is insignificant at 5 percent critical level. This result does not conform to the buffer stock model which predicts a positive relationship between import and foreign reserves. One of the reasons that could be adduced for this contradiction is that Nigeria's importers depend highly on foreign reserves for their foreign exchange needs, and as such Nigeria's external reserve reacts negatively to imports. Lastly, call rate (a proxy for opportunity cost of holding reserves) has an insignificant negative impact on Nigeria's foreign reserves. 
Table 3: Long run Estimates

Dep. Var: $\ln R$

\begin{tabular}{llll}
\hline Variable & Coefficient & t-Stat. & Prob. \\
\hline $\ln (-1)$ & 0.9994 & 132.3514 & 0.0000 \\
$\ln \sigma(-1)$ & 0.0035 & 4.2243 & 0.0000 \\
$\ln (-1)$ & -0.0050 & -1.0698 & 0.2860 \\
$\ln I M(-1)$ & -0.0049 & -0.9471 & 0.3448 \\
$\ln$ VOL(-1) & -0.2744 & -2.2345 & 0.0266 \\
Constant & 0.0591 & 0.9361 & 0.3504 \\
R-squared & 0.9945 & & \\
F-statistic & 7096.0750 & & \\
Prob (F-statistic) & 0.0000 & & \\
\multicolumn{5}{l}{ Source: Computed by Authors }
\end{tabular}

\subsection{Short run estimates}

In Table 4 presents the results of the short-run estimates. The estimated short-run coefficient of error correcting parameter (ECM) for the model is statistically significant and has the correct sign. This is a further proof of the presence of a stable long run relationship between foreign reserves and all the independent variables. The coefficient of error correction parameter of -0.808 shows evidence of fast adjustment towards long-run equilibrium. $80.8 \%$ disequilibrium is corrected on monthly basis by changes in foreign reserves. The value of the F-statistic is 8.98 and it is significant ( $p$-value $<0.05$ ). This implies that the overall short-run regression model is appropriate.

Table 4: Results from Short run estimation Dep.Var.: dlnR

\begin{tabular}{llll}
\hline Variable & Coefficient & t-Stat. & Prob. \\
\hline dlnR(-1) & $1.179848^{* *}$ & 6.012397 & 0.0000 \\
dln $(-1)$ & $0.026341^{* *}$ & 3.690756 & 0.0003 \\
dlnr $(-1)$ & -0.0008 & -0.1502 & 0.8808 \\
dlnIM(-1) & 0.0130 & 1.1557 & 0.2492 \\
dlnVOL(-1) & -0.1711 & -1.9612 & 0.0851 \\
ECM(-1) & $-0.964741^{* *}$ & -4.505012 & 0.0000 \\
Constant & -0.001423 & -0.435434 & 0.6637 \\
F-statistic & 8.982299 & & \\
Prob (F-statistic) & 0.000000 & & \\
* and ** indicate significance at 5\% and 1\% level respectively \\
Computed by Authors
\end{tabular}

The short-run estimation of the model is highly similar to the long run estimates. However, the coefficient of import is positive but insignificant in the short run. The sign of all parameters in the short run conform to the "buffer stock model". In the result, adjustment cost has a 
significant positive impact on foreign reserves in Nigeria. A percent change in one period lag in adjustment cost leads, on the average, to about 0.026 percent increase in Nigeria's foreign reserves. This result corroborates the findings of Barten (1982).

Opportunity cost of holding reserves, proxied by call rate, has a negative but an insignificant effect on foreign reserves in Nigeria. The lack of robustness of this relationship may be attributable to underdeveloped nature of the Nigeria's financial market, low level of reserve that could not sustain investment, over reliance on the roles of reserves for cushioning and stabilising the effects of exchange rate volatilities. This result is consistent with that of Irefin and Yaaba (2012).

The result of the short run estimates also confirms that exchange rate volatility plays important roles in foreign reserves accumulation in Nigeria. Exchange rate volatility has a negative significant effect on foreign reserves at 10 percent critical level. The result shows that a percent increase in exchange rate volatilities could bring about 0.17 percent decrease in foreign reserves accumulation in Nigeria. This finding is consistent with the statement of the CBN that foreign reserves are held to safeguard the value of the domestic currency.

Import has an insignificant positive impact on foreign reserves in Nigeria. This could imply an insignificant role of import in foreign reserve accumulation in the short-run. This shows that optimum reserves holding in Nigeria is more sensitive to precautionary than mercantilist motives. The result is consistent with the findings of Shijaku (2012) and Irefin and Yaaba (2012).

Table 5 presents diagnostic tests on the possible presence of serial correlation and heteroscedaticity in our model (equation 6). Null hypotheses of these tests are that serial correlation and heteroscedasticity are presence in equation 6 . The results show the rejection of the null hypotheses since the p-values of F-statistics of Breusch Godfrey test of serial correlation and Breusch Pagan test of heteroscedasticity are greater than 0.05.Thus, the specification (equation 6) is free of serial correlation and heteroscedaticity. Also, misspecification test presented in Table 6 by Ramsey RESET test indicates that for all test statistics, at a 5\% significance level, null hypothesis of no misspecification error is accepted. Therefore, the model used in this study is well specified. 
Table 5: Diagnostic Tests

\begin{tabular}{llll}
\hline & F-statistic $(p$-value) & $\begin{array}{l}\text { Obs*R-squared } \\
\text { Chi-square })\end{array}$ & (Prob. \\
\hline Serial Correlation Test & $1.9315(0.1477)$ & $3.9643(0.1378)$ & \\
Heteroscedasticity Test & $2.1260(0.0921)$ & $10.4010(0.0836)$ & \\
\hline Computed by Authors & & &
\end{tabular}

Table 6: Ramsey RESET Test

\begin{tabular}{llcc}
\hline & Value & df & $p$-value \\
\hline t-statistic & 1.292501 & 193 & 0.1977 \\
F-statistic & 1.670559 & $(1,193)$ & 0.1977 \\
Likelihood ratio & 1.732318 & 1 & 0.1881 \\
\hline
\end{tabular}

Source: computed by Authors

Figure 2 shows the level of optimum and actual reserves. The figure indicates that Nigeria's actual foreign reserve management is not consistent with the optimal reserves holding which take cognizance of opportunity cost and benefits of holding reserves. The Nigeria's actual foreign reserves are below the optimum foreign reserves between 2002 and 2005 and between 2010 and 2011. Also, while the actual reserves showed little fluctuations, optimum reserves experienced high oscillations, reflecting the vulnerabilities of the Nigerian economy to external shocks including but not limited to currency crisis, oil price volatility and global financial crisis.

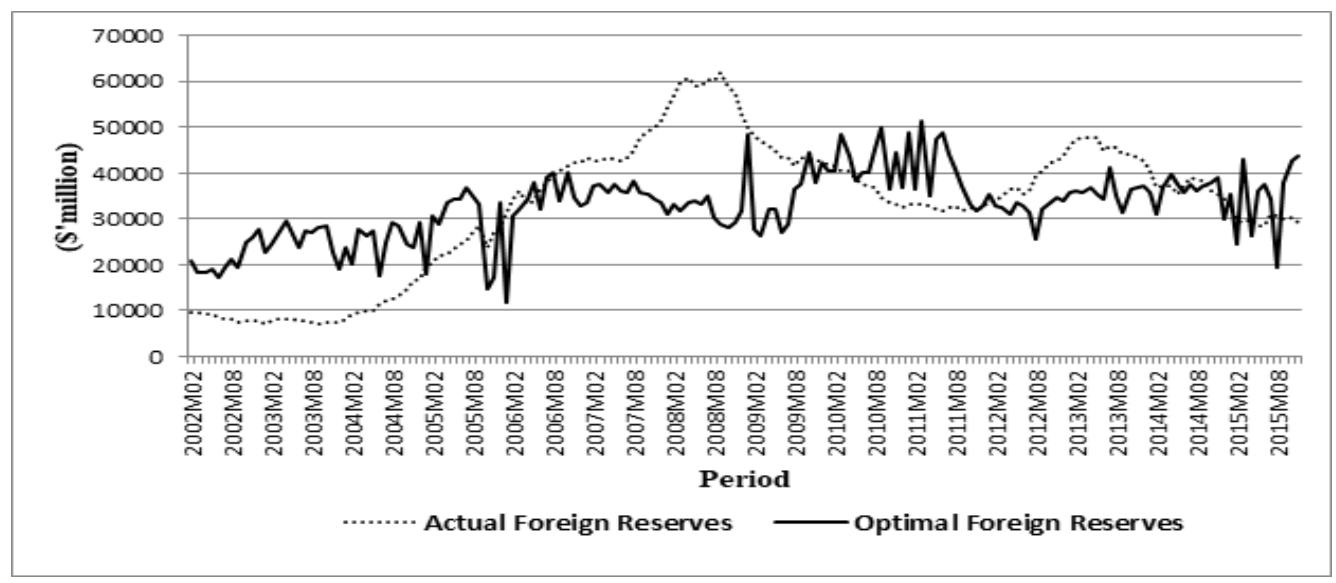

Figure 2: Trends of Optimal and Actual foreign Reserves 


\section{Conclusion and Policy Recommendations}

The search for optimal foreign reserves that is consistent with economic situation of a country has led to the emergence of studies in this area. Some of these studies have theoretically examined what determine foreign reserves and have devised means of ascertaining whether or not a country's reserves is adequate, appropriate and shocks accommodating. The traditional approach relies on some indicators such as import cover, foreign reserve to short-term debt to adjudge reserves adequacy and foreign reserve to broad money supply. The optimisation method seeks to determine optimum reserves by minimising the gap between the benefit and cost of holding reserves. This study, adopting the 'buffer stock model' advanced by Frenkel and Jovanovic (1981), determined the optimal level of foreign reserves for Nigeria. This paper used the ARDL approach to estimate the optimal foreign reserves function.

The results show that the Nigeria's optimal reserves level response to adjustment cost of holding reserves and exchange rate volatility and that import and opportunity cost have insignificant impact on Nigeria's optimal foreign reserves. Both short run and long run estimates of the buffer stock model support the fact that foreign reserves holding in Nigeria is more sensitive to precautionary than mercantilist motives. This study, therefore, concludes that the desire to protect and stabilize the value of local currencies is the major motivation for the accumulation of reserves in Nigeria.

Thus, the CBN, as the custodian of Nigeria's foreign reserves, needs to implement effective foreign reserves policy that will take cognizance of external shocks especially exchange rate volatilities. Also, given that Nigeria's foreign reserve is affected considerably by variations in adjustment cost; the $\mathrm{CBN}$ should avoid significant depletion of foreign reserves.

\section{References}

Abiola, A.G. \& Adebayo, F.O. (2013). Channeling the Nigeria's foreign exchange reserves into alternative investment outlets: a critical analysis. International Journal of Economics and Financial Issues, 3(4), 813-826.

Afrin, S., Sarder, W., \& Nabi, G. (2014). The demand for international reserves of Bangladesh. Working Paper Series: WP 1402.

Aizenman, J., \& Lee, J. (2005). International reserves: precautionary vs. mercantilist views, theory and evidence. IMF Working Paper Working Paper /05/198. 
Aizenman, J., \& Marion, N. (2003). The high demand for international reserves in the Far East: What Is Going On? Journal of the Japanese and International Economies. 17: $370-400$

Alfaro, L. \& Kanczuk, F. (2007). Optimal reserves management and sovereign debt, NBER Working Paper 13216, National Bureau of Economic, Cambridge, Massachusetts.

Batten, D. (1982). Central banks demand for foreign reserves under fixed and floating exchange rates. Federal Reserve Bank of St. Louis.

Ben-Bassat, A., \& Gottlieb, D. (1992). Optimal international reserves and sovereign risk. Journal of International Economics. 33, 345-362.

Calvo, G., Alejandro I., \& Rudy L. (2012). Optimal holdings of international reserves with special reference to balance-sheet effects and sudden stop. Mimeo.

Calvo, G. \& Reinhart, C. (2002). Fear of Floating. Quarterly Journal of Economics, 117(2), $379-408$

Central Bank of Nigeria (2017). Reserve Management, Retrieved from http://www.cbn.gov.ng/IntOps/ReserveMgmt.asp

Cheung, Y. W. \& Ito, H. (2007). A cross-country empirical analysis of international reserves. Mimeo.

Dabla-Norris, E., Kim, J. I., \& Shirono, K. (2011). Optimal precautionary reserves for lowincome countries: a cost-benefit analysis. International Monetary Fund WP/11/249 IMF Working Paper.

Daud, S.N.M., \& Ahmad, A.H. (2013). The Cost of international reserves: an empirical analysis from Malaysia. Journal of Economic Cooperation and Development, 34(4), 23-46.

Dhar S. (2013). Reserve accumulation and global financial stability: a critical assessment of IMF concerns. IEO Background Paper (BP/12/03)

Edwards, S., (1985). On the interest rate elasticity of the demand for international reserves: some evidence from developing countries, Journal of International Money and Finance, 4: 287-295.

Flood, R. P. \& Marion, N. P. (2002). Holding international reserves in an era of high capital mobility. IMF Working Paper No.02/62, Washington D.C.: International Monetary Fund.

Fosu, O. E. \& Magnus, J. F. (2006). Bounds testing approach to cointegration: an examination of foreign direct investment, trade and growth relationships. American Journal of Applied Sciences, 3(11), 2079-2085. 
Frenkel, J.A., \& Jovanovic, B. (1981). On transactions and precautionary demand for money. NBER Working Papers 0288, National Bureau of Economic Research, Inc.

Green, R., \& Torgeson, T. (2007). Are high foreign exchange reserves in emerging markets a blessing or a burden? United States Department of the Treasury.

Greenspan, A. (1999). Currency reserves and debt. Remarks at the World Bank Conference on Trends in Reserve Management (Washington, DC, April 29).

Heller, H. R., (1966). Optimal international reserves. The Economic Journal,76(302), 296311.

International Monetary Fund. (2000). Debt-and reserves-related indicator of external vulnerability. Washington: International Monetary Fund, a paper prepared by the Policy Development and Review Department in Consultation with other Departments, March 2000.

International Monetary Fund (2003). Assessing Reserve Adequacy. Available at https://www.imf.org/external/np/pp/eng/2011/021411b.pdf

International Monetary Fund (2017). Article IV Consultation—Press Release; Staff Report; And Statement By The Executive Director For Nigeria (2017). IMF Country Report No. $17 / 80$

Irefin, D., \& Yaaba, B. N. (2012). Determinants of foreign reserves in Nigeria: an autoregressive distributed lag approach, CBN Journal of Applied Statistics, 2(2), 63-82.

Jalil, A. \& Bokhari, S. (2008). The Optimal Demand for Foreign Exchange Reserves in Pakistan. International Journal of Applied Econometrics and Quantitative Studies, $5(1), 33-48$

Jeanne, O., \& Ranciere, R. (2008). The Optimal level of International Reserves for emerging Market Countries: A new formula and applications. CEPR Discussion Paper 6723.

Kakar M. K., Kakar A. khan W. \& Waliullah (2010). The Long-run Relationship among Money, Income and the Price Level in Pakistan. Journal of Economics and Sustainable Development, 2(3), 117-128.

Kaminsky, G. \& Reinhart, C. (1999). The twin crises: the causes of banking and balance of payments problems. American Economic Review, 89(3), 473-500.

Kim, J. S., Li, J., Rajan, R., Sula, O., \& Willett, T. D. (2005). Reserve adequacy in Asia revisited: new benchmarks based on the size and composition of capital flows. In Claremont-KIEP Conference Volume on Monetary and Exchange Rate Arrangements.

Mbeng-Mezui C. A., \& Duru, U. (2013). Holding excess foreign reserves versus infrastructure finance: what should Africa do? African Development Bank Group Working Paper series No. 178. 
Mohanty, M.S., \& Turner, P. (2006). Foreign exchange reserve accumulation in emerging markets: what are the domestic implications? BIS Quarterly Review, 39-53.

Molapo, S. S. (2016). Optimal international reserves in Lesotho. European Scientific Journal, 12(13), 282-294.

Olomola, P. \& Ajayi, I, (2018). The determinants of international reserves in West African States. Global Journal of Human-Social Science, 18(4), 1-9.

Oputa N. C. \& Oguleye T.S. (2010). External reserves accumulation and the estimation of the adequacy level for Nigeria, CBN Economic and Financial Review, 48/3(1), 1-30.

Oyeniran, I.W. \& Maryam, W. T. (2015). Financial market integration and economic growth: an experience from Nigeria, Nigeria Deposit Insurance Corporation Quarterly Journal 26(1/2),31-35.

Pesaran, M. H., Shin, Y., \& Smith, R. J. (2001). Bounds testing approaches to the analysis of long-run relationships. Journal of Applied Econometrics, 16(3), 289-326.

Prabheesh (2013). Optimum international reserves and sovereign risk: evidence from India, Journal of Asian Economics, 28, 76-86.

Rodríguez, C. S. \& Funk, K., (2012). Estimation of optimal international reserves for Costa Rica: a micro-founded approach. Research Document No. 01-2012, The Research Paper Series of the Economic Research Department from Central Bank of Costa Rica.

Sanusi, K.A., Meyer, D.F., \& Hassan, A.S. (2019). An investigation of the determinants of foreign exchange reserves in Southern African countries. Journal of International Studies, 12(2), 201-212.

Senibi, V., Oduntan, E., Uzoma, O., Senibi, E. \& Oluwaseun, A. (2016). Public Debt and External Reserve: The Nigerian Experience (1981-2013). Economics Research International, http://dx.doi.org/10.1155/2016/1957017

Suheyla, O., \& Yaman, B., (2005). Optimal versus adequate level of international reserves: evidence for Turkey. Applied Economics, 37, 1557-1569.

Triffin, R., (1960). Gold and the dollar crisis. Yale University Press, New Haven.

Shijaku, G. (2012). Optimal level of reserve holding: an empirical investigation in the case of Albania. MPRA Paper 79091, University Library of Munich, Germany.

Tule M. K., Egbuna, E.N., Sagbamah, J.E.L., Abdusalam, S.A, Ogundele, O.S,. Oduyemi A.O, \& Oladunni, S.(2015). Determination of optimal foreign exchange reserves in Nigeria. Central Bank of Nigeria Working Paper Series CBN/WPS/01/2015/06.

Winjuholds, J., \& Kapteyn, A. (2001), Reserve Adequacy in Emerging Market Economies. IMF Working Paper 01/143, Washington DC: International Monetary Fund. 